\title{
ANALISIS HUKUM PENERAPAN PASAL 103 UNDANG-UNDANG NOMOR 35 TAHUN 2009 TENTANG NARKOTIKA TERHADAP PECANDU NARKOTIKA DALAM PUTUSAN No : 788/Pid.Sus/2019/PN Bpp
}

\section{LEGAL ANAL YSIS OF THE IMPLEMENTATION OF ARTICLE 103 LAW NUMBER 35 OF 2009 ON NARCOTICS OF NARCOTICS ADDICTS IN DECISION Number 788/Pid.Sus/2019/PN Bpp}

\author{
Suhadi $^{1}$, Rosdiana $^{2}$, Ries Fitri Amalia ${ }^{3}$ \\ Fakultas Hukum Universitas Balikpapan \\ Jalan Pupuk Raya Kelurahan Damai, Balikpapan, Kalimantan Timur \\ Email: suhadi@uniba-bpn.ac.id, riesfa28@gmail.com
}

\begin{abstract}
ABSTRAK
Penanggulangan narkotika yang dilakukan untuk mengurangi jumlah pecandu Narkotika berupa rehabilitas adalah upaya penanggulangan yang lebih efektif untuk mengurangi jumlah pencandu Narkotika. Namun dalam kenyataannya sebagian besar pencandu Narkotika berakhir dengan hukuman penjara bukan rehabilitas. Seperti perkara tindak pidana Narkotika putusan Nomor: 788/Pid.Sus/2019/PN Bpp terhadap terdakwa Hasan di mana hakim memutus terdakwa dengan pidana penjara selama 3 (tiga) tahun bukan Rehabilitas padahal terdakwa merupakan korban pecandu Narkotika. Berdasarkan pasal 103 Undang-Undang Nomor 35 Tahun 2009 tentang Narkotika bahwa hakim diberikan pedoman untuk menempatkan pecandu Narkotika ke dalam lembaga rehabilitasi terbukti atau tidaknya dalam persidangan. Berdasarkan hasil analisis hukum, pertimbangan hakim dalam putusan Nomor: 788/Pid.Sus/2019/PN Bpp terhadap Pecandu Narkotika bahwa majelis hakim tidak mempertimbangkan dan lebih teliti dalam memperhatikan setiap ayat dalam Pasal 127 ayat (1), Pasal 127 ayat (2) dan hakim hanya memperhatikan Pasal 127 ayat (1). Dalam pasal 127 ayat (2) bahwa dalam memutus perkara sebagaimana pada ayat (1) hakim wajib memperhatikan Pasal 54, Pasal 55 dan Pasal 103. Sudah jelas bahwa Pasal 127 ayat (1) merupakan satu kesatuan dengan Pasal 127 ayat (2). Dalam Pasal 54 juga menyatakan bagi pecandu Narkotika rehabiltas bersifat wajib dan Pasal 103 Ayat (1) tersebut memberikan pedoman bagi hakim untuk menempatkan pecandu Narkotika ke dalam lembaga rehabilitas. Berdasarkan syarat-syarat klasifikasi Surat Edaran Mahkamah Agung Nomor 04 Tahun 2010 bahwa terdakwa juga telah memenuhi syarat-syarat tersebut untuk menjalani rehabilitas dan hakim juga tidak memperhatikan adanya alat bukti berupa surat rekomendasi rehabilitas dari BNN (Badan Narkotika Nasional) Nomor R/363/IX/KA/RH.01/2019/BNNK-BPN dengan saran dapat diberikan pelayanan rehabilitas.
\end{abstract}

Kata Kunci: Narkotika, Rehabiltas, Pecandu.

\begin{abstract}
Narcotics countermeasures carried out to reduce the number of narcotics addicts in the form of rehabilitation is a more effective countermeasure to reduce the number of Narcotics addicts. But in reality most Narcotics addicts end up with prison sentences instead of rehabilitation. Such as narcotics crime case verdict Number: 788/Pid.Sus/2019/PN Bpp against defendant Hasan where the judge sentenced the defendant to prison for 3 (three) years instead of Rehabilitation even though the
\end{abstract}


defendant was a victim of Narcotics addicts. Based on article 103 of Law No. 35 of 2009 on Narcotics that judges are given guidelines for placing Narcotics addicts into rehabilitation institutions proven or not in court. Based on the results of legal analysis, the judge's consideration in the verdict Number: 788/Pid.Sus/2019/PN Bpp against Narcotics Addicts that the panel of judges did not consider and more thoroughly in considering each paragraph in Article 127 paragraph (1), Article 127 paragraph (2) and the judge only pays attention to Article 127 paragraph (1). In article 127 paragraph (2) that in deciding the case as in paragraph (1) the judge must pay attention to Article 54, Article 55 and Article 103. It is clear that Article 127 paragraph (1) is a unity with Article 127 paragraph (2). Article 54 also states that narcotics addicts are mandatory and Article 103 Paragraph (1) provides guidelines for judges to place Narcotics addicts into rehabilitative institutions. Based on the classification requirements of The Supreme Court Circular Letter No. 04 of 2010 that the defendant has also fulfilled these conditions to undergo rehabilitation and the judge also did not pay attention to the existence of evidence in the form of a letter of recommendation for rehabilitation from BNN (National Narcotics Agency) Number R/363/IX/KA/RH.01/2019/BNNK-BPN with the suggestion that rehabilitation services can be provided.

Keywords: Narcotics, Rehabilitation, Addicts.

\section{PENDAHULUAN}

\section{A. Latar Belakang}

Peredaran dan penggunaan Narkotika di Indonesia bisa dikatakan sudah masuk pada keadaan darurat Narkotika. Banyak penangkapan yang telah dilakukan oleh penegak hukum seperti BNN (Badan Narkotika Nasional), Kepolisian dan Petugas Bea dan Cukai dan adanya aturan yang sudah diterapkan pada pelaksanaannya belum berjalan efektif sehingga tidak menutup kemungkinan jumlah pengguna Narkotika terus menerus meningkat dari tahun ke tahun. ${ }^{1}$ Namun upaya tersebut ternyata belum cukup menurunkan peredaran dan pengguna Narkotika di Indonesia. Melihat keadaan tersebut presiden telah membuat suatu kebijakan dalam bentuk Peraturan Presiden Nomor 47 Tahun 2019 Tentang Perubahan Atas Peraturan Presiden 23 Tahun 2010 Tentang Badan Narkotika Nasional. Peraturan tersebut mengenai kewajiban rehabilitas bagi Para pecandu Narkotika, karena sanksi pidana berupa pemenjaraan bagi pengguna Narkotika tidak akan memberikan efek jera terhadap pengguna Narkotika.

Upaya penanggulangan Narkotika yang dilakukan untuk mengurangi jumlah pecandu Narkotika tersebut tidaklah cukup dengan satu cara, melainkan harus dilaksanakan dengan rangkaian tindakan yang berkesinambungan dari berbagai macam unsur, baik dari lembaga pemerintah maupun non pemerintah . Rangkaian tindakan tersebut mencakup usaha-usaha yang bersifat preventif, represif, dan rehabilitative (rehabilitas). Berdasarkan Pasal 103 ayat (1) Undang-Undang Nomor 35 Tahun 2009 Tentang Narkotika berbunyi hakim yang memeriksa perkara pecandu Narkotika dapat :

a. Memutuskan untuk memerintahkan yang bersangkutan menjalani pengobatan dan/atau perawatan melalui rehabilitas jika pecandu Narkotika tersebut terbukti bersalah melakukan tindak pidana Narkotika; atau

b. Menetapkan untuk memerintahkan yang bersangkutan menjalani pengobatan dan/atau perawatan melalui rehabilitas jika pecandu Narkotika tersebut tidak terbukti bersalah melakukan tindak pidana Narkotika.

\footnotetext{
${ }^{1}$ Moh. Taufik Makro, dkk, 2005, Tindak Pidana Narkotika, Bogor, Ghalia, hlm.45
} 
Pasal di atas juga di perkuat dengan aturan SEMA (Surat Edaran Mahkamah Agung) Nomor 04 Tahun 2010 Tentang Penempatan Penyalahgunaan, Korban Penyalahgunaan Dan Pecandu Narkotika Ke Dalam lembaga Rehabilitas Medis dan Rehabilitas Sosial.

Secara tersirat kewenangan ini mengakui bahwa korban pecandu Narkotika, selain sebagai pelaku tindak pidana juga sekaligus korban dari kejahatan itu sendiri yang dalam sudut viktimologi kerap disebut dengan self victimization dan victimless crime. Sehingga dengan memberikan rehabilitas terhadap pecandu Narkotika adalah upaya penanggulangan yang lebih efektif untuk mengurangi jumlah pencandu Narkotika dari pada sanksi pidana. ${ }^{2}$

Peradilan terhadap pecandu Narkotika sebagian besar berakhir dengan hukuman pemenjaraan dan bukan hukuman rehabilitas sebagaimana yang termaksud dalam undang-undang tersebut, yang terjadi bahwa masih banyak Pecandu Narkotika dijatuhkan hukuman penjara di atas 5 (lima) tahun bukan hukuman rehabilitas, seharusnya penegak hukum hingga para hakim menghukum seluruh Pecandu melalui hukuman rehabilitas sesuai dengan tujuan dan kewenangan hakim yang diberikan sesuai ketetapan Undang-Undang Nomor 35 Tahun 2009 Tentang Narkotika karena telah banyak Pencandu Narkotika yang tertangkap lagi oleh aparat kepolisian setelah menjalani masa hukuman dipenjara. Salah satu alasan tindak pidana hukuman penjara tidak membuat pelakunya jera adalah tidak dapat lepas dari ketergantungan terhadap Narkotika dan terpaksa kembali menyalahgunakan Narkotika dan terbukti tidak dapat menurunkan jumlah Pencandu Narkotika, dengan penjaranya pengguna Narkotika tidak akan menyelesaikan masalah bahkan mungkin akan menimbulkan masalah yang lain. ${ }^{3}$

Berdasarkan uraian di atas, penulis merasa tertarik untuk meneliti mengenai suatu perkara tindak pidana Khusus Narkotika berdasarkan putusan Nomor: 788/Pid.Sus/2019/PN Bpp di Pengadilan Negeri Balikpapan dengan terdakwa bernama Hasan. Kronologi kasusnya secara singkat: berawal pada hari minggu tanggal 25 Agustus 2019 sekitar pukul 22.00 Wita terdakwa Hasan berangkat ke Samarinda menggunakan mobil travel dari rumahnya menuju Samarinda, kemudian pada tanggal 02 September 2019 terdakwa menuju pasar Segeri Samarinda dengan tujuan untuk membeli Narkotika jenis sabu-sabu dengan cara langsung ke loket tempat jualan Sdr. Roni (DPO), kemudian sampai di loket uang terdakwa serahkan ke Sdr. Roni (DPO) selanjutnya Sdr. Roni menyerahkan sabu-sabu sebanyak 1 (satu) poket seharga Rp.200.00 (dua ratus ribu rupiah) kemudian setelah mendapat sabusabu tersebut terdakwa kembali pulang ke rumah balikpapan dengan menggunakan mobil travel dan sekitar pukul 19.00 Wita terdakwa sampai di rumahnya langsung istirahat, selanjutnya keesokan harinya sekitar pukul 12.00 Wita terdakwa selesai makan langsung merakit bong untuk memakai sabu-sabu, namun baru dua kali terdakwa menghisap sabu-sabu tersebut dari bongnya kemudian datang 2 (dua) orang yang berpakaian preman mengetok pintu rumah terdakwa kemudian oleh terdakwa dibukakan pintu dan kedua orang tersebut langsung mengamankan terdakwa dan melakukan penangkapan kepada terdakwa sambil menunjukan surat tugas, bahwa kemudian 2 (dua) orang tersebut yang ternyata anggota kepolisian dari Badan

\footnotetext{
${ }^{2}$ Dikdik M. Arief Mansur dan Elisatris Gultom,2007,Urgensi Perlindungan Korban Kejahatan, Jakarta, PT.Raja Grafindo Persada,hlm.100

${ }^{3}$ Megawati Marcos,'Tinjauan Yuridis Tentang Pemidanaan Pecandu Narkotika”, Jurnal , 2014, hlm.5
} 
Narkotika Nasional yaitu Saksi Novi Hari Setiawan,SH dan Saksi Ridho Suhada, selanjutnya dilakukan penggeledahan dan ditemukan barang bukti berupa 2 (dua) paket sabu dalam plastik klip kecil, 3 (tiga) buah alat hisap bong, 2 (dua) buah korek api gas dan 1 (satu) buah Hp merek LG warna hitam, bahwa selanjtnya saksi Novi Hari Setiawan,SH dan Saksi Rido Suhada kepada terdakwa siapa milik sabu-sabu tersebut dan diakui oleh terdakwa bahwa sabu-sabu tersebut miliknya yag dibelinya di Samarinda dari Sdr. Roni (DPO) seharga Rp.200.00 (dua ratus ribuh rupiah), selanjutnya terdakwa dan barang bukti di bawa ke Polres Balikpapan untuk proses lebih lanjut. Putusan tersebut layak diteliti karena pada putusan Nomor: 788/Pid.Sus/2019/PN Bpp dimana hakim memutus terdakwa dengan pidana penjara selama 3 (tiga) tahun bukan Rehabilitas.

Berdasarkan penerapan singkat kasus di atas peneliti bermaksud untuk mengkaji mengenai Putusan Nomor: 788/Pid.Sus/2019/PN Bpp yang berkaitan dengan Pencandu Narkotika dalam studi kasus dengan judul: “Analisis Hukum Penerapan Pasal 103 Undang-Undang Nomor 35 Tahun 2009 Tentang Narkotika Terhadap Pecandu Narkotika (Studi Kasus Putusan No : 788/Pid.Sus/2019/PN Bpp).

\section{B. Rumusan Masalah}

Apakah yang menjadi dasar hukum pertimbangan hakim dalam memeriksa, mengadili, dan memutus terhadap Pecandu Narkotika berdasarkan Putusan Nomor: 788/Pid.Sus/2019/PN Bpp?

\section{Metode}

Metode yang dilakukan dalam penelitian ini adalah menggunakan pendekatan penelitian. Pendekatan penelitian yang digunakan dalam penulisan ini adalah pendekatan yuridis normatif yaitu penelitian hukum kepustakaan yang mengacu pada pendekatan perundang-undangan. Pendekatan perundang-undangan dalam hal ini Undang-undang Nomor 35 Tahun 2009 tentang Narkotika, Surat Edaran Mahkamah Agung Nomor 04 Tahun 2010 Tentang Penempatan Penyalahgunaan, Korban Penyalahgunaan Dan Pecandu Narkotika Ke Dalam lembaga Rehabilitas Medis dan Rehabilitas Sosial.

\section{Tinjauan Pustaka}

\section{a. Pengertian Narkotika}

Secara umum yang dimaksud Narkotika adalah zat atau obat yang berasal dari tanaman atau bukan tanaman, baik sintetis maupun semi sintetis, yang dapat menyebabkan penurunan atau perubahan kesadaran hilangnya rasa, mengurangi sampai menghilangkan rasa nyeri, dan dapat menimbulkan ketergantungan ${ }^{4}$.

Istilah Narkotika yang dipergunakan disini bukanlah "narcotics" pada farmasi (farmacologies), melainkan sama artinya dengan "drug" yaitu sejenis zat yang bila dipergunakan (dimasukan dalam tubuh) akan membawa pengaruh terhadap tubuh si pemakai. Pengaruh tersebut berupa :

1) Mempengaruhi kesadaran;

2) Memberi dorongan yang dapat berpengaruh terhadap perilaku manusia;

\footnotetext{
${ }^{4}$ Deputi Bidang Pencegahan,2017, Narkoba dan Permasalahannya, Jakarta, BNN,hlm.3
} 
3) Adapun pengaruh-pengaruh tersebut dapat berupa:

a) Penenang;

b) Perangsang (bukan rangsangan seks);

c) Menimbulkan halusinasi (pemakainya tidak mampu membedakan antara khayalan dan kenyataan, kehilangan kesadaran akan waktu dan tempat).

Dalam Pasal 1 angka (13) Undang-Undang Nomor 35 Tahun 2009 Tentang Narkotika, pecandu Narkotika adalah orang yang menggunakan atau menyalahgunakan Narkotika dan dalam keadaan ketergantungan pada Narkotika. Dalam Pasal 1 angka (15) Undang-Undang Nomor 35 Tahun 2009 Tentang Narkotika adalah orang yang menggunakan Narkotika tanpa hak atau melawan hukum. ${ }^{5}$

Salah satu akibat yang ditimbulkan oleh pengguna Narkotika adalah timbulnya suatu keadaan dimana si pemakainya menjadi lupa atau tidak sadarkan diri dibawa pengaruh Narkotika, sehingga seseorang dapat melepaskan diri dari situasi konflik. Seseorang akan melarikan diri dari situasi yang tidak dapat diatasinya. Akan tetapi sebab dari kesulitan itu sama sekali tidak dapat dihilangkan.

\section{b. Jenis - Jenis Narkotika}

Sehubung dengan adanya penggolongan tentang jenis-jenis Narkotika sebagaimana dimaksud dalam rumusan Pasal 6 ayat (1) ditetapkan dalam penjelasan umum Undang-Undang Nomor 35 Tahun 2009 Tentang Narkotikan seperti terurai dibawah ini :

1. Narkotika Golongan I

Dalam ketentuan ini yang dimaksud Narkotika golongan I adalah Narkotika yang hanya dapat digunakan dalam terapi, serta mempunyai potensi sangat tinggi mengakibatkan ketergantungan.

2. Narkotika Golongan II

Dalam ketentuan ini yang dimaksud dengan Narkotika golongan II adalah Narkotika berkhasiat pengobatan dan banyak digunakan dalam terapi dan/atau tujuan pengembangan ilmu pengetahuan serta mempunyai tinggi mengakibatkan ketergantungan.

3. Narkotika Golongan III

Dalam ketentuan ini yang dimaksud dengan Narkotika golongan III adalah Narkotika berkhasiat pengobatan dan banyak digunakan dalam terapi dan/atau untuk tujuan pengembangan ilmu pengetahuan serta mempunyai potensi ringan mengakibatkan ketergantungan.

\section{c. Dampak Pencandu Narkotika}

Dampak pencandu Narkotika pada seseorang sangat tergantung pada jenis Narkoba yang dipakai, kepribadian pemakai dan situasi atau kondisi pemakai. Secara umum, dampak kecanduan Narkotika dapat terlihat pada fisik, psikis maupun, sosial seseorang. ${ }^{6}$

1) Dampak terhadap fisik

\footnotetext{
${ }^{5}$ Ibid.,hlm.4

${ }^{6}$ Haryanto, "Dampak Penyalahgunaan Narkoba", http://belajarpsikologi.com/dampakpenyalahgunaan-narkoba/ diakses pada tanggal 15 mei 2019,pukul 19:09 WITA
} 
a) Gangguan pada system syaraf (neurologis) seperti: kejang-kejang, halusinasi, gangguan kesadaran, kerusakan syaraf tepi;

b) Gangguan pada jantung dan pembuluh darah (kardiovaskuler) seperti: infeksi akut otot jantung, gangguan peredaran darah;

c) Gangguan pada kulit (dermatologis) seperti: penahan (abses), alergi, eksim ;

d) Gangguan pada paru-paru (pulmoner) seperti: penekanan fungsi pernapasan, kesukaran bernafas, pengerasan jaringan paru-paru;

e) Sering saki kepala, mual-mual dan muntah, murus-murus, suhu tubuh meningkat, pengecilan hati dan sulit tidur;

f) Dampak Penyalahgunaan Narkotika terhadap kesehatan reproduksi adalah gangguan padaendokrin, seperti : penurunan fungsi hormone reproduksi (estrogen, progesterone, testosterone), serta gangguan fungsi seksual;

g) Dampak Penyalahgunaan Narkotika terhadap kesehatan reproduksi pada remaja perempuan antara lain perubahan periode menstruasi, ketidakteraturan menstruasi, dan amenorhoe (tidak haid);

h) Bagi pengguna Narkotika melalui jarum suntik, khususnya pemakaian jarum suntik secara bergantian, risikonya adalah tertular penyakit seperti hepatitis B, C, dan HIV yang hingga saat ini belum ada obatnya;

i) Penyalahgunaan Narkotika bisa berakibat fatal ketika terjadi over dosis yaitu konsumsi Narkotika melebihi kemampuan tubuh untuk menerimanya. Over dosis bisa menyebabkan kematian.

2) Dampak Terhadap Psikis

a) Lamban kerja, ceroboh kerja, sering tegang dan gelisah;

b) Hilang kepercayaan diri, apatis pengkhayal, penuh curiga;

c) Agitatif, menjadi ganas dan tingkah laku yang brutal;

d) Sulit berkonsentrasi, perasaan kesal dan tertekan;

e) Cenderung menyakiti diri perasaan tidak aman, bahkan bunuh diri.

3) Dampak mengganggu keharmonisan keluarga

a) Akan mengganggu keharmonisan keluarga;

b) Merongsong keluarga;

c) Membuat aib keluarga;

d) Hilangnya harapan keluarga;

e) Mengganggu keamanan dan ketertiban;

f) Mendorong tindak kejahatan;

g) Mengakibatkan hilangnya kepercayaan;

h) Menimbulkan beban ekonomi dan sosial yang besar;

Dalam kehidupan sehari-sehari di masyarakat termasuk juga dalam lingkungan sekolah, banyak dijumpai remaja yang hanya menjadi pemakai Narkoba, Pengedar ataupun kedua-duanya. Sebagai pengedar dan juga sebagai pemakai. Dalam lingkungan masyarakat yang lebih luas banyak dijumpai ulah para pengedar dan pemakai narkoba yang meresahkan, mereka tidak segan-segan untuk melakukan tindak kriminal seperti menodong, mencopet, merampok, mencuri, marak hanya semata-mata untuk mendapatkan Narkotika. Bagi mereka yang sudah sampai pada tingkat ketergantungan yang tinggi, apapun resikonya tidak diperhitungkan lagi yang penting untuk mendapatkan Narkotika.

\section{d. Rehabilitas Terhadap Pecandu Narkotika}

Rehabilitas adalah usaha pemulihan korban Narkotika sehingga kembali dapat melaksanakan fungsionalitas sosialnya yaitu dapat melaksanakan tugas hidupnya secara normal dan wajar. Program rehabilitas merupakan serangkaian upaya yang 
terkoordinasi dan terpadu, terdiri atas upaya-upaya medis, bimbingan mental, psikososial, keagamaan dan pendidikan untuk meningkatkan kemampuan penyesuaian diri, kemandirian, dan menolong diri sendiri serta mencapai kemampuan fungsional sesuai dengan potensi yang dimiliki baik fisik, mental, sosial dan ekonomi. Rehabilitas bagi pecandu Narkotika dilakukan dengan maksud untuk memulihkan dan/atau mengembangkan kemampuan fisik, mental, dan sosial penderita yang bersangkutan. Rehabilitas terhadap pecandu Narkotika menganut teori treatment sebab rehabilitas terhadap pecandu Narkotika merupakan suatu proses kegiatan pengobatan secara terpadu untuk membebaskan pecandu dari ketergantungan. Hal tersebut sesuai dengan pemidanaan yang dimaksudkan pada aliran teori treatment yaitu untuk memberi tindakan perawatan (treatment) dan perbaikan (rehabilitation) kepada pelaku kejahatan sebagai pengganti dari penghukuman. Pelaku kejahatan adalah orang yang sakit sehingga membutuhkan perawatan (treatment) dan perbaikan (rehabilitation). ${ }^{7}$

Ketentuan sanksi tindakan berupa rehabilitas terhadap pecandu Narkotika diatur di dalam Pasal 54 dan Pasal 55 Undang-Undang Nomor 35 Tahun 2009 tentang Narkotika :

Pasal 54

"Pecandu Narkotika dan korban penyalahgunaan Narkotika wajib menjalani rehabilitas medis dan rehabilitas sosial “

Pasal 55

(1) Orang tua atau wali dari pecandu Narkotika yang belum cukup umur wajib melaporkan kepada pusat kesehatan masyarakat, rumah sakit, dan/atau lembaga rehabilitasi medis dan rehabilitasi sosial yang ditunjuk oleh pemerintah untuk mendapatkan pengobatan dan/atau perawatan melalui rehabilitas medis dan rehabilitas sosial.

(2) Pecandu Narkotika yang sudah cukup umur wajib melaporkan diri atau dilaporkan oleh keluarga kepada pusat kesehatan masyarakat, rumah sakit, dan/atau lembaga rehabilitas medis dan rehabilitas sosial yang ditunjuk oleh pemerintah untuk mendapatkan pengobatan dan/atau perawatan melalui rehabilitas medis dan rehabilitas sosial.

Ketentuan lain diatur dalam Pasal 1 angka (1) Peraturan Pemerintah Nomor 25 Tahun 2011 Tentang Pelaksanaan Wajib Lapor Pecandu Narkotika menyatakan “ Wajib lapor adalah kegiatan melaporkan diri yang dilakukan oleh pecandu Narkotika yang sudah cukup umur atau keluarganya, dan/atau orang tua atau wali dari pecandu Narkotika yang belum cukup umur kepada institusi penerima wajib lapor untuk mendapatkan pengobatan dan/atau perawatan melalui rehabilitasi medis dan rehabilitasi sosial".

Tindakan rehabilitas merupakan penanggulangan yang bersifat represif yaitu penanggulangan yang dilakukan setelah terjadinya tindak pidana, dalam hal ini Narkotika, yang berupa pembinaan atau pengobatan terhadap para pengguna Narkotika. Dengan upaya-upaya pembinaan atau pengobatan tersebut diharapkan nantinya korban penyalahgunaan dan pecandu Narkotika dapat kembali normal dan berperilaku baik dalam kehidupan bermasyarakat. ${ }^{8}$

\footnotetext{
${ }^{7}$ Barda Nawawi Arief, 2009, RUU KUHP Baru Sebuah Restrukturisasi/Rekonstruksi Sistem Hukum Pidana Indonesi, Semarang, Badan Penerbit Universitas Dipenogoro, hlm.23-24

${ }^{8}$ http://www.psychologymania.com/2012/08/pengertian-rehabilitasi-narkoba.html diakses terakhir tanggal 11 mei 2019 pukul 15.23 wita
} 


\section{e. Tindak Pidana Narkotika}

Undang-Undang Nomor 35 Tahun 2009 Tentang Narkotika menyatakan bahwa setiap perbuatan yang tanpa hak berhubungan secara langsung maupun tidak langsung dengan Narkotika adalah bagian dari tindak pidana Narkotika. Pada dasarnya pengguna Narkotika hanya boleh digunakan untuk kepentingan pengobatan serta ilmu kepentingan-kepentingan sebagaimana disebutkan di atas, maka perbuatan tersebut dikualifikasikan sebagai tindak pidana Narkotika. Hal tersebut ditegaskan oleh ketentuan Pasal 7 Undang-Undang Nomor 35 Tahun 2009 tentang Narkotika menyatakan bahwa :

"Narkotika hanya dapat digunakan untuk kepentingan pelayanan kesehatan dan/atau pengembangan ilmu pengetahuan dan teknologi."

Tindak pidana Narkotika diatur dalam Pasal 11 sampai dengan Pasal 138 Undang-Undang Nomor 35 Tahun 2009 Tentang Narkotika. Dalam segi perbuatannya ketentuan pidana diatur oleh undang-undang tersebut dapat di kelompokan menjadi 9 (Sembilan) antara lain: ${ }^{9}$

1) Kejahatan yang menyangkut produksi Narkotika;

2) Kejahatan yang menyangkut jual beli Narkotika;

3) Kejahatan yang menyangkut pengangkutan dan transit Narkotika;

4) Kejahatan yang menyangkut penguasaan Narkotika;

5) Kejahatan yang menyangkut penyalahgunaan Narkotika;

6) Kejahatan yang menyangkut tidak melapor pecandu Narkotika;

7) Kejahatan yang menyangkut label dan publikasi Narkotika;

8) Kejahatan yang menyangkut jalannya peradilan Narkotika;

9) Kejahatan yang menyangkut penyitaan dan pemusnahan Narkotika.

Pada umumnya, jenis-jenis tindak pidana Narkotika dapat dibedakan menjadi berikut ini :

1) Tindak pidana yang menyangkut penyalahgunaan Narkotika dibedakan menjadi dua macam yaitu perbuatannya untuk orang lain dan untuk diri sendiri;

2) Tindak pidana yang menyangkut produksi dan jual beli Narkotika Tindak pidana yang menyangkut produksi dan jual beli disini bukan hanya dalam arti sempit, akan tetapi termasuk pula perbuatan ekspor impor dan tukar menukar Narkotika;

3) Tindak pidana yang menyangkut pengangkutan Narkotika tindak pidana dalam arti luas termasuk perbuatan membawa, mengirim, mengangkut, dan mentransit Narkotika. Selain itu, ada juga tindak pidana di bidang pengangkutan Narkotika yang khusus ditujukan kepada nahkoda atau kapten penerbang karena tidak melaksanakan tugasnya dengan baik;

4) Tindak pidana yang menyangkut penguasaan Narkotika;

5) Tindak pidana yang menyangkut laporan pecandu Narkotika orang tua atau wali memiliki kewajiban untuk melaporkan pecandu Narkotika. Karena jika kewajiban tersebut tidak dilakukan dapat merupakan tindak pidana bagi orang tua atau wali dan pecandu yang bersangkutan;

6) Tindak pidana yang menyangkut label dan publikasi seperti yang diketahui bahwa pabrik obat diwajibkan mencantumkan label pada kemasan Narkotika baik dalam bentuk obat maupun bahan baku Narkotika. Kemudian untuk dapat

\footnotetext{
${ }^{9}$ Gatot Supramono, 2001, Hukum Narkoba Indonesia, Jakarta, Djambatan, hlm.154
} 
dipublikasikan Pasal 46 Undang-Undang Nomor 35 Tahun 2009 Tentang Narkotika syaratnya harus dilakukan pada media cetak ilmiah kedokteran atau media cetak ilmiah farmasi. Apabila tidak dilaksanakan dapat merupakan tindak pidana;

7) Tindak pidana menyangkut penyitaan dan pemusnahan Narkotika barang yang ada hubungannya dengan tindak pidana dilakukan penyitaan untuk dijadikan barang bukti perkara bersangkutan dan barang bukti tersebut harus diajukan dalam persidangan. Status barang bukti ditentukan dalam putusan pengadilan. Apabila barang bukti tersebut terbukti dipergunakan dalam tindak pidana maka harus ditetapkan dirampas untuk dimusnahkan. Dalam tindak pidana Narkotika ada kemungkinan barang bukti yang disita berupa tanaman yang jumlahnya sangat banyak, sehingga tidak mungkin barang bukti tersebut diajukan ke persidangan semuanya. Dalam hal ini penyidik wajib membuat berita acara sehubungan dengan tindakan penyidikan berupa, penyitaan, penyisihan, dan pemusnahan kemudian dimasukkan dalam berkas perkara. Sehubungan dengan hal tersebut, apabila penyidik tidak melaksanakan tugasnya dengan baik merupakan tindak pidana;

8) Tindak pidana yang menyangkut pemanfaatan anak di bawah umur tindak pidana dibidang Narkotika tidak seluruhnya dilakukan orang dewasa tetapi ada kalanya kejahatan ini dilakukan pula bersama-sama dengan anak dibawah umur ( belum genap 18 tahun usianya). Oleh karena itu perbuatan memanfaatkan anak dibawah umur untuk melakukan kegiatan Narkotika merupakan tindak pidana.

\section{PEMBAHASAN}

Sebelum memutus perkara tindak pidana narkotika hakim selalu memperhatikan hal-hal yang dapat menjadi suatu pertimbangan-pertimbangan yaitu Pertimbangan Hakim yang bersifat yuridis dan non yuridis Pertimbangan yang bersifat yuridis adalah pertimbangan hakim yang didasarkan pada faktor-faktor yang terungkap di dalam persidangan dan oleh undang-undang telah ditetapkan sebagai hal yang harus dimuat di dalam putusan ${ }^{10}$, sedangkan pertimbangan hakim yang non yuridis yaitu : 1) Akibat perbuatan terdakwa; 2) kondisi diri terdakwa.

Selain pertimbangan bersifat yuridis dan non yuridis, hakim juga memperhatikan pertimbangan-pertimbangan berdasarkan Pasal 197 huruf f KUHAP, dalam menjatuhkan putusan, hakim yang memeriksa perkara harus melakukan pertimbangan-pertimbangan mengenai faktor apa yang memberatkan dan meringankan pidana yang akan dijatuhkan kepada terdakwa.

Pertimbangan hakim dalam menjatuhkan putusan mencerminkan rasa keadilan baik bagi korban maupun bagi terdakwa. Untuk menentukan bahwa terdakwa terbukti bersalah atau tidak hakim harus berpedoman pada sistem pembuktian sebagaimana diatur dalam Pasal 184 KUHAP sebagai berikut : ${ }^{11}$

\footnotetext{
${ }^{10}$ Adi Waseso Bambang\& Edy Herdyanto, Pertimbangan Hakim Dalam Menjatuhkan Sanksi Pidana Penjara Tanpa Rehabilitasi Medis Terhadap Terdakwa Penyalahguna Narkotika Bagi Diri Sendiri, Verstek, Volume 7 No.1, 2019,hlm.6

${ }^{11}$ Aswin Pramudita, Pertimbangan Hukum Hakim Menjatuhkan Sanksi Pidana Penjara Terhadap Penyalahgunaan Narkotika Tanpa Menerapkan Rehabilitasi Medis (Studi Putusan Nomor 100/Pid.Sus/2015/PN.Skt), Verstek, Volume 5 Nomor 2,hlm.168
} 
"Hakim tidak boleh menjatuhkan pidana kepada seseorang kecuali apabila dengan sekurang-kurangnya dua alat bukti yang sah ia memperoleh keyakinan bahwa suatu tindakan pidana benar-benar terjadi dan bahwa terdakwa lah yang bersalah melakukannya"

Dasar pertimbangan hakim dalam menjatuhkan pidana akan sangat menentukan apakah putusan seseorang hakim dianggap adil atau menentukan apakah putusan nya dapat dipertanggungjawabkan atau tidak.

Dari kasus posisi yang sudah diuraikan sebelumnya, adapun dasar pertimbangan hakim dalam mengadili Putusan Nomor: 788/Pid.Sus/2019/PN Bpp, terhadap terdakwa Hasan, maka dasar pertimbangan-pertimbangan hakim dalam menjatuhkan putusan yaitu:

\section{Pertimbangan Berdasarkan Dasar Hukum}

Dalam Kasus Putusan Nomor: 788/Pid.Sus/2019/PN Bpp, dasar hukum hakim dalam menjatuhkan putusan sanksi pidana penjara terhadap terdakwa Hasan berdasarkan Dasar hukum Pasal 127 ayat (1) huruf a Undang-Undang Nomor 35 Tahun 2009 tentang Narkotika dengan unsur-unsur sebagai berikut:

a. Unsur Objektif yaitu setiap penyalahgunaan,

Mengenai unsur "setiap penyalahgunaan" adalah seperti terdapat dalam Pasal 1 ayat (15) Undang-Undang Nomor 35 Tahun 2009 tentang Narkotika yaitu orang yang menggunakan Narkotika tanpa hak dan melawan hukum. Unsur "setiap penyalahgunaan" terpenuhi berdasarkan alasan-alasan sebagai berikut:

1) Dalam persidangan terdakwa telah mengakui identitasnya yang dicantumkan dalam surat dakwaan sebagai identitas dirinya, yang mana sesuai pula dengan keterangan saksi-saksi.

2) Hakim mempertimbangkan bahwa terdakwa tidak mempunyai hak atau perbuatannya melawan hukum karena terdakwa tidak mempunyai izin dari yang berwenang dalam mengkonsumsi Narkotika jenis sabu-sabu sehingga terdakwa melanggar Pasal 8 Undang-Undang Nomor 35 Tahun 2009 tentang Narkotika terlebih dahulu membatasi penggunaan Narkotika golongan I yang hanya digunakan untuk kepentingan pengembangan ilmu pengetahuan dan teknologi dan untuk reagensia diagnostik, serta reagensia laboratorium setelah mendapatkan persetujuan Menteri atas rekomendasi Kepala Badan Pengawas Obat dan Makanan.

3) Berdasarkan hasil pemeriksaan UPTD Laboratorium kesehatan Samarinda tanggal 13 September 2019 yang ditandatangani oleh Dr.Gusti Adheeida selaku pemeriksa dan selaku penanggung jawab bahwa sampel urine milik terdakwa positif $(+)$ mengandung Metamfaamin.

b. Unsur Subyektif yaitu Narkotika Golongan I Bagi Diri Sendiri

Bahwa yang dimaksud dengan "Narkotika golongan I" adalah seperti yang terdapat dalam penjelasan Pasal 6 ayat (1) huruf a Undang-Undang Nomor 35 Tahun 2009 tentang Narkotika, yaitu Narkotika yang hanya dapat digunakan untuk tujuan pengembangan ilmu pengetahuan dan tidak digunakan dalam terapi, serta mempunyai potensi sangat tinggi mengakibatkan ketergantungan. Unsur "Narkotika Golongan I bagi diri sendiri" terpenuhi berdasarkan alasan-alasan sebagai berikut:

1) Bahwa berdasarkan keterangan saksi-saksi, bahwa terdakwa telah ditangkap oleh saksi Novi Hari Setyawan dan saksi Ridho Dyuhada yang merupakan anggota polisi dari Polda Kota yang mana pada saat itu terdakwa sedang 
mengkonsumsi Narkotika jenis sabu-sabu di dalam kamar terdakwa untuk digunakan atau dikonsumsi sendiri.

2) Bahwa saat dilakukannya penggeledahan telah ditemukan 2 (dua) bungkus paket klip kecil yang berisi serbuk kristal wama putih yang diduga sabu-sabu dengan berm 0.10 gram bruto tersebut disisihkan 0,04 gram dan barang bukti sabu-sabu seberat 0.04 gram disisihkan menjadi 0,20 gram untuk dipergunakan dalam pemeriksaan laboratorium dan berdasarkan laporan pengujian barang bukti secara laboratorium Balai Besar Pengawas Obat dan Makanan Di Samarinda No R- PP.01.01.110.1102.09.19.0161 tanga1 17 September 2019 yang ditandatangani oleh Ratih Wulandari, S Farm. Apt berkesimpulan sediaan dalam bentuk serbuk kristal, tidak berwarna dan tidak berbau dalam bungkus plastik positif $(+)$ mengandung METAMFETAMINA yang termasuk dalam daftar Narkotika golongan 1 UU R1 No.35 Tahun 2009 tentang Narkotika.

\section{Pertimbangan Berdasarkan Alat Bukti}

Fakta-fakta yang terungkap di persidangan yang menjadi pertimbangan hakim dilihat dari alat-alat bukti yang pada saat pemeriksaan di pengadilan. Alat-alat bukti berdasarkan :

a. Keterangan Saksi

1) Bahwa saksi Novi Hari Setiawan dan saksi Ridho Syuhada melakukan penangkapan tersebut berdasarkan laporan informasi masyarakat bahwa sering adanya peredaran gelap dan penyalahgunaan Narkotika jenis sabu-sabu, setelah melakukan penyelidikan tim menyimpulkan bahwa benar di sebuah rumah di Jl. Persatuan Nomor 16 Rt.001 telah terjadi penyalahgunaan dan peredaran Narkotika, kemudian Saksi melakukan penangkapan terhadap terdakwa Hasan, yang mana pada saat itu terdakwa lagi mengkonsumsi Narkotika jenis satu di dalam kamarnya dan menemukan barang bukti berupa 2 (dua) buah plastik cetik berisikan Kristal putih yang diduga mengandung Methamphetamine (sabu) seberat 0,54 (nol koma lima puluh empat)gram, 3 (tiga) buah alat hisap sabu (bong), 2 (dua) buah korek api gas, 1 (satu) buah HP merek LG warna hitam dan saksi menjelaskan orang yang ditangkap tersebut adalah terdakwa Hasan.

2) Bahwa saksi Ramces Paulus Simbolon diminta oleh petugas BNN kota Balikpapan untuk menyaksikan penggeledahan, dan saksi menjelaskan yang melihat kejadian penangkapan tersebut hanya saksi dan petugas BNN Kota Balikpapan. Saksi juga melihat barang bukti yang ditemukan petugas saat melakukan penggeledahan dan saksi menjelaskan benar seorang laki-laki yang ditangkap adalah terdakwa Hasan.

b. Surat

Surat yang diajukan di persidangan yang dijadikan alat bukti dan menjadi pertimbangan hakim yaitu :

1) Hasil surat keterangan pemeriksaan UPTD Laboratorium kesehatan Samarinda tanggal 13 September 2019 yang ditandatangani oleh Dr. Gusti Adheeida bahwa sampel urin terdakwa positif (+) mengandung metamfetamin.

2) Hasil surat keterangan pengujian dari laboratorium Balai Besar Pengawas Obat dan Makanan Di Samarinda No R- PP.01.01.110.1102.09.19.0161 tanga1 17 September 2019 yang ditandatangani oleh Ratih Wulandari, S Farm. Apt berkesimpulan sediaan dalam bentuk serbuk kristal, tidak berwarna dan tidak berbau dalam bungkus plastik positif mengandung 
METAMFETAMINA yang termasuk dalam daftar Narkotika golongan $1 \mathrm{UU}$ R1 No.35 Tahun 2009 tentang Narkotika.

\section{c. Petunjuk}

Penyesesuaian antara semua alat-alat bukti yaitu keterangan saksi yang satu dengan yang lain telah sesuai.

d. Keterangan Terdakwa

Terdakwa dalam pengadilan membenarkan semua keterangan saksi yang diajukan ke persidangan, terdakwa juga membenarkan bahwa barang bukti berupa Narkotika yang disita dan diamankan adalah milik terdakwa.

\section{Pertimbangan Berdasarkan Barang Bukti}

Hakim telah menetapkan barang bukti berupa :
a. 2 (satu) poket Narkotika jenis sabu-sabu dengan berat kotor 0.14 (nol koma empat belas)gram.
b. 3 (tiga) alat hisap atau bong.
c. 1 (satu) buah HP merk LG warna hitam.

\section{Pertimbangan Berdasarkan Keyakinan Hakim}

Berdasarkan keyakinan hakim dalam memutus perkara Narkotika terhadap terdakwa Hasan, yaitu bahwa terdakwa Hasan telah terbukti secara sah dan bersalah melakukan tindak Pidana Narkotika berdasarkan alat-alat bukti dan barang bukti yang seusai dengan undang-undang diajukan di persidangan . Bahwa hakim berpendapat bahwa perbuatan terdakwa tersebut bertentangan dengan hukum objektif dimana dalam Undang-Undang Nomor 35 Tahun 2009 tentang Narkotika telah jelas mengatur pelarangan penggunaan Narkotika, selain itu terdakwa juga tidak memiliki izin dari pejabat dan berwenang dalam mengkonsumsi Narkotika jenis sabu dan Hakim juga tidak menemukan hal-hal yang dapat menghapuskan pertanggungjawaban pidana baik sebagai alasan pembenar dan alasan pemaaf.

Berdasarkan dasar pertimbangan Hakim putusan Nomor 788/Pid.Sus/2019/PN Bpp di atas bahwa terdakwa Hasan diputus oleh Hakim telah melanggar Pasal 127 ayat 1 huruf a Undang-Undang Nomor 35 Tahun 2009 Tentang Narkotika dan dijatuhkan pidana penjara selama 3 (tiga) tahun sesuai dakwaan kesatu Jaksa.

Dalam Pasal 1 angka 13 Undang-Undang Nomor 35 Tahun 2009 Tentang Narkotika disebutkan bahwa "Pecandu Narkotika adalah orang yang menggunakan atau menyalahgunakan Narkotika dan dalam keadaan ketergantungan pada Narkotika, baik secara fisik maupun psikis". Berdasarkan Pasal tersebut dapat disimpulkan bahwa seorang pecandu Narkotika merupakan "self victimizing victim". Self victimizing victim menurut Schafer adalah mereka yang menjadi korban karena kejahatan yang dilakukan sendiri $^{12}$. Karena pecandu Narkotika menderita sindrom ketergantungan akibat penyalahgunaan Narkotika yang dilakukannya sendiri. ${ }^{13}$

Dalam undang-undang Narkotika terdapat bahwa seorang pecandu Narkotika dapat dilakukan tindakan berupa rehabilitas yang berdasarkan Pasal 54 Undang-Undang Nomor 35 Tahun 2009 Tentang Narkotika yang menyebutkan: “ Pecandu Narkotika dan korban penyalahgunaan Narkotika wajib menjalani rehabilitas medis dan rehabilitas sosial". Dari penjelasan pasal tersebut dapat kita pahami, bahwa pecandu maupun korban penyalahgunaan Narkotika wajib menjalani rehabilitas medis dan rehabilitas sosial. Salah satu alat bukti yang menunjukan terdakwa Hasan merupakan korban

\footnotetext{
${ }^{12}$ Sri Hartini, Korban Penyalahgunaan Kekuasaan Rezim Orde Baru, Jurnal Civics, Vol.4, No.2, Hlm.57

${ }^{13}$ Damar Bastiar, Penegakan Hukum Terhadap Penyalahgunaan Dan Pencegahan Pengguna Narkotika Di Indonesia,Jurnal Rechtens, Vol.8,No.2, 2019,hlm 219
} 
pecandu Narkotika yaitu adanya alat bukti yang tidak diperhatikan oleh Hakim dan tidak diajukan oleh Jaksa Penuntut Umum di dalam persidangan yaitu berupa Surat rekomendasi rehabiltas dari BNN (Badan Narkotika Nasional) Nomor R/363/IX/KA/RH.01/2019/BNNK-BPN tanggal 09 September 2019 yang dibuat dan ditandatangani oleh ketua tim Assessment Terpadu. Dalam surat rekomendasi rehabilitas tersebut dijelaskan bahwa Tim Assessment Terpadu merekomendasikan terdakwa diberikan pelayanan rehabilitasi medis atau rehabilitasi sosial karena terdakwa merupakan korban pecandu Narkotika.

Selain itu dalam pasal 127 ayat (2) dijelaskan : “ Dalam memutus perkara sebagaimana pada ayat (1) hakim wajib memperhatikan ketentuan sebagaimana dimaksud dalam Pasal 54, Pasal 55 dan Pasal 103.

Dalam Pasal 54 yang menyebutkan :

"pecandu Narkotika dan korban Penyalahgunaan Narkotika wajib menjalani rehabiltas medis dan rehabilitas sosial"

Dalam Pasal 55 yang menyebutkan :

(1) Orang tua atau wali dari pecandu Narkotika yang belum cukup umur wajib melaporkan kepada pusat kesehatan masyarakat, rumah sakit, dan/atau lembaga rehabilitasi medis dan rehabilitasi sosial yang ditunjuk oleh pemerintah untuk mendapatkan pengobatan dan/atau perawatan melalui rehabilitasi medis dan rehabilitasi sosial.

(2) Pecandu Narkotika yang sudah cukup umur wajib melaporkan diri atau dilaporkan oleh keluarganya kepada pusat kesehatan masyarakat, rumah sakit, dan/atau lembaga rehabilitasi medis dan rehabilitasi sosial yang ditunjuk oleh pemerintah untuk mendapatkan pengobatan dan/atau perawatan melalui rehabilitasi medis dan rehabilitasi sosial.

Sedangkan dalam Pasal 103 menyebutkan :

(1) hakim yang memeriksa perkara pecandu Narkotika dapat:

a. Memutuskan untuk memerintahkan yang bersangkutan menjalani pengobatan dan/atau perawatan melalui rehabilitas jika pecandu Narkotika tersebut terbukti bersalah melakukan tindak pidana Narkotika; atau

b. Menetapkan untuk memerintahkan yang bersangkutan menjalani pengobatan dan/atau perawatan melalui rehabilitas jika pecandu Narkotika tersebut tidak terbukti bersalah melakukan tindak pidana Narkotika.

(2) Masa menjalani pengobatan dan/atau perawatan bagi pecandu Narkotika sebagaimana dimaksud pada ayat (1) huruf a diperhitungkan sebagai masa menjalani hukuman.

Pasal 103 diperjelas di dalam aturan SEMA (Surat Edaran Mahkamah Agung) Nomor 04 Tahun 2010 Tentang Penempatan Penyalahgunaan, Korban Penyalahgunaan Dan Pecandu Narkotika Ke Dalam lembaga Rehabilitas Medis dan Rehabilitas Sosial menyebutkan bahwa :

" Penerapan pemidanaan dimaksud Pasal 103 huruf a dan b Undang-Undang Republik Indonesia Nomor 35 Tahun 2009 Tentang Narkotika hanya dapat dijatuhkan pada klasifikasi tindak pidana sebagai berikut : 
a. Terdakwa pada saat ditangkap oleh penyidik polri dan penyidik BNN dalam kondisi tertangkap tangan;

b. Pada saat tertangkap tangan sesuai butir a di atas ditemukan barang bukti pemakaian 1 (satu) hari dengan perincian antara lain sebagai berikut:

1) Kelompok metamphetamine (shabu) $: 1$ gram

2) Kelompok MDMA (ekstasi) :2,4 gram $=8$ butir

3) Kelompok Heroin $: 1,8$ gram

4) Kelompok kokai :1,8 gram

5) Kelompok Ganja : :5 gram

6) Daun Koka : 5 gram

7) Meskalin

8) Kelompok Psilosybin

$: 5$ gram

9) Kelompok LSD (d-lysergic acid diethylamide

10) Kelompok PCP (phencyclidine) : 3 gram

11) Kelompok Fentanil : : 1 gram

12) Kelompok Metadon :0,5 gram

13) Kelompok Morfin : :1,8 gram

14) Kelompok Petidin :0,96 gram

15) Kelompok Kodein : :72 gram

16) Kelompok Bufrenorfin : $32 \mathrm{mg}$

c. Surat uji laboratorium positif menggunakan Narkotika berdasarkan permintaan penyidik;

d. Perlu surat keterangan dari dokter jiwa/psikiater pemerintah yang ditunjuk oleh hakim;

e. Tidak terdapat bukti bahwa yang bersangkutan terlibat dalam peredaraan gelap Narkotika.

Berdasarkan dasar pertimbangan hakim yang dijelaskan sebelumnya dalam mempertimbangkan dan memutus perkara terhadap terdakwa Hasan hakim hanya memperhatikan fakta-fakta persidangan saja. Majelis hakim tidak mempertimbangkan dan lebih teliti dalam memperhatikan setiap ayat dalam Pasal 127 ayat (1), Pasal 127 ayat (2) dan hakim hanya memperhatikan Pasal 127 ayat (1). Dalam pasal 127 ayat (2) bahwa dalam memutus perkara sebagaimana pada ayat (1) hakim wajib memperhatikan Pasal 54, Pasal 55 dan Pasal 103. Sudah jelas bahwa Pasal 127 ayat (1) merupakan satu kesatuan dengan Pasal 127 ayat (2). Dalam Pasal 54 juga menyatakan bagi pecandu Narkotika rehabiltas bersifat wajib dan Pasal 103 Ayat (1) tersebut memberikan pedoman bagi hakim untuk menempatkan pecandu Narkotika ke dalam lembaga rehabilitasi medis dan rehabilitasi sosial terbukti atau tidaknya dalam persidangan jika pecandu Narkotika tersebut telah terbukti memenuhi syarat klasifikasi SEMA (Surat Edaran Mahkamah Agung) Nomor 04 Tahun 2010.

Berdasarkan syarat klasifikasi SEMA (Surat Edaran Mahkamah Agung) Nomor 04 Tahun 2010 sudah jelas bahwa terdakwa Hasan telah terbukti memenuhi syarat klasifikasi SEMA (Surat Edaran Mahkamah Agung) Nomor 04 Tahun 2010 dengan bukti yaitu terdakwa pada saat ditangkap oleh penyidik BNN dalam kondisi tertangkap tangan pada tanggal 03 September 2019 sekitar pukul 18.30 Wita tim BNN K013 Balikpapan melakukan Penangkapan terhadap terdakwa Hasan, yang mana pada saat itu terdakwa lagi mengkonsumsi Narkotika jenis sabu-sabu di dalam kamar terdakwa. Pada saat tertangkap tangan ditemukan barang bukti pemakaian 1 (satu) hari pada tanggal 03 September 2019 sekitar pukul 12.00 Wita anggota BNN mengamankan tersangka 
selanjutnya melakukan penggeledahan dan ditemukan barang bukti berupa 2 (dua) paket sabu seberat 0.14 gram ,barang bukti ditemukan tidak melewati 24 jam dan tidak melebih perincian ketentuan syarat SEMA. Surat uji laboratorium positif menggunakan Narkotika berdasarkan permintaan penyidik berdasarkan hasil pemeriksaan UPTD Laboratorium Kesehatan Samarinda tanggal 13 September 2019 yang ditandatangani oleh Dr.Gustu Adheeida selaku pemeriksaan dan penanggung jawab bahwa sampel urin terdakwa positif $(+)$ mengandung metamfaamin dan dalam putusan terdakwa menggunakan Narkotika golongan I bagi diri sendiri dalam hal ini terdakwa tidak terbukti terlibat dalam peredaraan gelap Narkotika. Dengan kata lain terdakwa merupakan korban pecandu Narkotika.

Berdasarkan uraian di atas terhadap terdakwa Hasan bahwa terdakwa telah memenuhi syarat klasifikasi SEMA (Surat Edaran Mahkamah Agung) Nomor 04 Tahun 2010 sehingga seharusnya dimana pertimbangan hakim dalam memutus perkara kasus terdakwa Hasan lebih memperhatikan aturan SEMA (Surat Edaran Mahkamah Agung) Nomor 04 Tahun 2010 untuk mewajibkan terdakwa menjalani rehabilitas berdasarkan ketentuan SEMA (Surat Edaran Mahkamah Agung) Nomor 04 Tahun 2010 karena pecandu Narkotika hanya pulih atau dapat disembuhkan dengan merehabilitasnya.

\section{PENUTUP}

\section{Kesimpulan}

Berdasarkan pertimbangan hakim dalam Putusan Nomor: 788/Pid.Sus/2019/PN.Bpp terhadap terdakwa Hasan tidak memperhatikan setiap ayat dalam Pasal 127 dan hanya memperhatikan Pasal 127 ayat (1) saja walaupun unsur-unsur dari pasal tersebut terpenuhi dalam perkara ini tetapi seharusnya hakim juga memperhatikan Pasal 127 ayat (2), dimana pasal tersebut menjelaskan dalam memutus perkara sebagaimana pada Ayat (1), hakim dapat memperhatikan ketentuan sebagaimana dimaksud dalam Pasal 54, Pasal 55, dan Pasal 103. Pasal-Pasal ini menjelaskan bahwa hakim diberikan pedoman untuk memberikan jaminan rehabilitas medis dan sosial jika terbukti atau tidaknya dalam persidangan dan Pasal 103 diperjelas dalam SEMA Nomor 2 Tahun 2010. Dalam SEMA Nomor 2 Tahun 2010 menjelaskan bahwa pecandu Narkotika dapat diberikan rehabilitas sosial dan rehabilitas medis apabila syarat-syarat klasifikasi dalam SEMA terpenuhi. Berdasarkan syarat-syarat klasifikasi SEMA bahwa terdakwa Hasan telah memenuhi syarat-syarat tersebut untuk menjalani rehabilitas dan dalam kasus ini hakim juga tidak memperhatikan adanya alat bukti yang tidak diajukan oleh Jaksa Penuntut Umum di dalam persidangan berupa surat rekomendasi rehabilitas dari BNN (Badan Narkotika Nasional)

Nomor R/363/IX/KA/RH.01/2019/BNNK-BPN tanggal 09 September 2019 yang dibuat dan ditandatangani oleh ketua tim assessment Terpadu dengan saran dapat diberikan pelayanan rehabilitas terhadap terdakwa Hasan.

2. Saran

Menurut pendapat penulis terhadap Putusan Nomor: 788/Pid.Sus/2019/PN Bpp terhadap terdakwa Hasan yang diputus oleh hakim berupa sanksi pidana penjara selama 3 (tiga) seharusnya terdakwa diputus sesuai peraturan perundang-undangan yang ada. Bahwa dalam kasus ini seharusnya Hakim 
memutus terdakwa Hasan untuk menjalani rehabilitas medis dan rehabiltas sosial sesuai SEMA Nomor 2 Tahun 2010 karena terdakwa telah memenuhi syarat-syarat klasifikasi dalam SEMA Nomor 2 Tahun 2010 sebagai korban pecandu Narkotika..

\section{DAFTAR PUSTAKA}

Andrisman ,Tri. Hukum Pidana. Bandar Lampung. Universitas Lampung. 2011.

Chazawi, Adami. Pelajaran Hukum Pidana Bagian 1. Jakarta.Penerbit PT.Raja Grafindo Persada. 2002.

Deputi Bidang Pencegahan. Narkoba dan Permasalahanya. Jakarta. BNN. 2017

Hamza, Andi.Hukum Acara Pidana Indonesia Edisi Kedua.Jakarta. Sinar Grafika.2017.

Huda,Chairul . Dari Pidana Menuju Kepada Tiada Pertanggungjawaban Pidana Tanpa Kesalahan. Jakarta. Pranada Media. 2006

Eddyono, Supriyadi Widodo Eddyono, Erasmus Napitupulu, dan Anggara.Meninjau Rehabiltasi Pengguna Narkotika Dalam Praktik Peradilan. Jakarta.Institute For Criminal Justice Reform.2016.

Supramono, Gatot . Hukum Narkoba Indonesia. Jakarta.Djambatan. 2001

Makro, Moh. Taufik. Tindak Pidana Narkotika. Bogor. Ghalia. 2005.

Mansur, Dikdik M. Arief dan Elisatris Gultom. Urgensi Perlindungan Korban Kejahatan. Jakarta. PT.Raja Grafindo Persada. 2007.

Mahrus, Hanafi, Sistem Pertanggungjawaban Pidana (Cetakan Pertama), Jakarta, Rajawali Pers.2015

Moeljatno. Asas-Asas Hukum Pidana. Jakarta. Rineka Cipta. 2008.

Nawawi Arief, Barda. RUU KUHP Baru Sebuah Restrukturisasi/Rekonstruksi Sistem Hukum Pidana Indonesi, Semarang, Badan Penerbit Universitas Dipenogoro.2009.

Undang-Undang Nomor 1 Tahun 1946 tentang Peraturan Hukum Pidana

Undang-Undang Nomor 35 tahun 2009 tentang Narkotika

Peraturan Presiden (Pepres ) Nomor 47 Tahun 2019 Tentang Perubahan Atas Peraturan Presiden 23 Tahun 2010 Tentang Badan Narkotika Nasional 
ISSN (Print): 2085-8477; ISSN (Online): 2655-4348

Surat Edaran Mahkamah Agung Nomor 10 Tahun 2010 Tentang Penempatan Penyalahgunanaan, Korban Penyalahgunaan Dan Pecandu Narkotika Ke Dalam lembaga Rehabilitas Medis dan Rehabilitas Sosial

Adi Waseso Bambang\& Edy Herdyanto. Pertimbangan Hakim Dalam Menjatuhkan Sanksi Pidana Penjara Tanpa Rehabilitasi Medis Terhadap Terdakwa Penyalahguna Narkotika Bagi Diri Sendiri.Verstek. Volume 7 No.1. 2019.

Aswin Pramudita. Pertimbangan Hukum Hakim Menjatuhkan Sanksi Pidana Penjara Terhadap Penyalahgunaan Narkotika Tanpa Menerapkan Rehabilitasi Medis (Studi Putusan Nomor 100/Pid.Sus/2015/PN.Skt). Verstek. Volume 5 Nomor 2.

Damar Bastiar. Penegakan Hukum Terhadap Penyalahgunaan Dan Pencegahan Pengguna Narkotika Di Indonesia. Jurnal Rechtens. Vol.8,No.2. 2019.

Sri Hartini, Korban Penyalahgunaan Kekuasaan Rezim Orde Baru, Jurnal Civics, Vol.4.

Haryanto, "Dampak Penyalahgunaan Narkoba”, http://belajarpsikologi.com/dampak-penyalahgunaan-narkoba/ diakses pada tanggal 15 mei 2019,pukul 19:09 WITA

http://www.psychologymania.com/2012/08/pengertian-rehabilitasi-narkoba.html 